\title{
Effect of External Radiant Heat Flux on Upward Fire Spread: Measurements on Plywood and Numerical Predictions
}

\author{
M. M. DELICHATSIOS, P. WU and M. A. DELICHATSIOS \\ Factory Mutual Research Corporation \\ Norwood, Massachusetts 02062, USA
}

G. D. LOUGHEED and G. P. CRAMPTON

National Research Council Canada

Ottawa, Ontario K1A OR6

C. QIAN, H. ISHIDA and K. SAITO

Department of Mechanical Engineering

University of Kentucky

Lexington, Kentucky 40506, USA

\begin{abstract}
In 1992, Factory Mutual Research Corporation (FMRC) and the National Research Council Canada (NRCC) initiated a joint research project on upward flame spread in which NRCC set-up and conducted upward flame spread tests using a large-scale radiant panel facility. The test procedure, developed as part of the joint research project, is described and the results obtained using plywood specimens are discussed. The University of Kentucky team was invited to join this project and to provide their expertise on automated infrared temperature measurements. The identical materials were also tested using a bench-scale fire test apparatus to provide input for the FMRC upward Flame Spread and Growth (FSG) model. An overview of the FSG model and the small-scale tests is provided in this paper. Simulations for both the small-scale and full-scale tests with plywood specimens are provided and comparisons made with the experimental results.
\end{abstract}

KEYWORDS: upward flame spread, pyrolysis, charring, plywood, modeling, small-scale test, full-scale test, heat release rate, surface temperature, heat flux, mass loss rate

\section{INTRODUCTION}

For several years, Factory Mutual Research Corporation (FMRC) has been developing models to simulate upward fire spread on a vertical surface [1]. In these models, vertical fire spread is simulated by assuming horizontal slices of the combustible material, at different elevations, are exposed to heat from a flame and from external sources. The model includes four major components: pyrolysis of the combustible material, gaseous burning, preheating of the unburned fuel and fire spread and extinguishment conditions. The material properties 
used as input for the models are obtained using bench-scale fire tests, including the FMRC $50 \mathrm{~kW}$ Flammability Apparatus. The model has been validated for non-charring materials, such as PMMA, and for charring materials, such as particleboard, using experimental measurements of upward fire spread on walls (up to $1.2 \mathrm{~m}$ high). This project addresses the effect of external flux on upward fire spread and tests the predictions of the model for plywood, a common construction material, and for larger heights.

Since flame spread and heat transfer increase with scale, upward fire spread accelerates quickly as the area of the burning material increases. However, most of the data available for validating upward flame spread models is limited primarily to $1.2 \mathrm{~m}$ heights or less and to non-charring materials such as PMMA [2,3]. Some data for upward fire spread on $2.44 \mathrm{~m}$ high specimens of charring materials (particleboard and lauan plywood) has been recently published by Hasemi et al [4].

In 1992, FMRC and the National Research Council Canada (NRCC) initiated a joint research project on upward flame spread. Within the scope of this project, NRCC set-up and conducted upward flame spread tests using the test procedure described in this paper. The identical materials were tested using bench-scale fire test apparatus to provide input for the FMRC Upward Flame Spread and Growth (FSG) model. An overview of the FSG model and the small-scale tests is provided in the next section. The data from the full-scale tests was used by FMRC to further develop and validate the FSG model. Test results from both the bench-scale and full-scale tests, with plywood specimens, are provided and comparisons with the model simulations are discussed.

\section{UPWARD FIRE SPREAD AND GROWTH MODEL}

Figure 1 shows a schematic of the upward Fire Spread and Growth (FSG) model [1] developed at FMRC. The model consists of four major components/modules: heat-up, pyrolysis, gaseous combustion and propagation of the pyrolysis front.

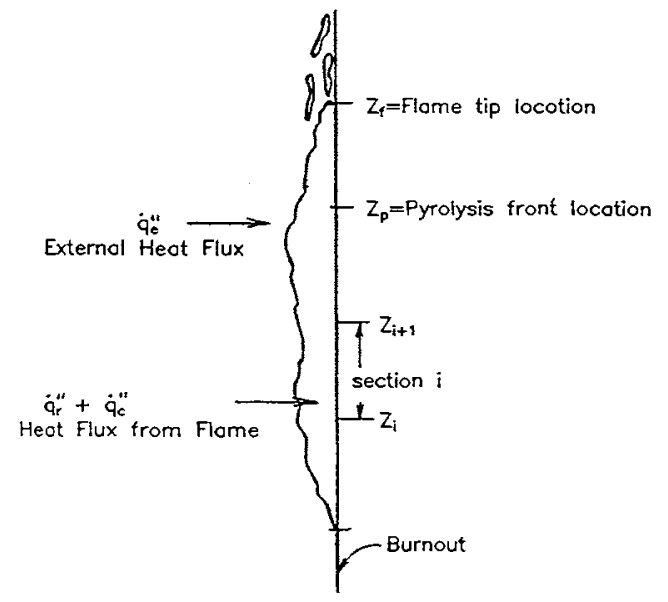

FIGURE 1. Schematic of the upward fire spread and growth model.

For the different components of the code, physical models or correlations (i.e., for flame flux) are used. For the heat-up and pyrolysis modules of the code, physical integral models have been developed which accurately predict (within 1-2\%) transient heat-up and transient pyrolysis when compared with exact pyrolysis solutions. The combustion module of 
the code calculates the heat flux distribution on the wall from the combustion of the pyrolyzing gases by providing expressions for the flame height, $\mathrm{Z}_{\mathrm{f}}$, the convective,

$\dot{q}_{c}^{\prime \prime}$, and radiative, $\dot{q}_{\mathrm{r}}^{\prime \prime}$, heat fluxes based on experimental data from the literature.

The components, as well as the whole algorithm of the upward FSG model, have been compared against exact analytical solutions, including transient heat-up, transient pyrolysis and flame spread, and experimental measurements for non-charring materials such as PMMA [5]. In the applications described in this paper, an extended version of the FSG model which includes charring effects was used [6,7].

\section{BENCH-SCALE TESTS AND PROPERTY MEASUREMENTS}

The flammability properties required as input to the upward FSG model were measured in the FMRC flammability apparatus [8]. With the FMRC apparatus, $98 \mathrm{~mm}$ diameter specimens were placed in $104 \mathrm{~mm}$ diameter horizontal dishes in the flammability apparatus. Insulation $(3 \mathrm{~mm})$ was placed below and on the sides of the samples to minimize heat losses. The samples were coated with a thin layer of carbon black to ensure that the incident external heat flux was all absorbed by the sample (emissivity $\varepsilon=1$ was assumed).

The samples were exposed to specified external heat fluxes, $\dot{\mathrm{q}}_{\mathrm{e}}^{\prime \prime}$, and the following measurements were made: time to piloted ignition, surface temperature history during heatup and pyrolysis, mass loss history due to pyrolysis in a nitrogen environment with $10 \% \mathrm{O}_{2}$ (no combustion), mass loss history in an atmospheric environment (with combustion and flames present), heat release rate and gaseous products of combustion.

From time to ignition measurements or surface temperature history measurements before pyrolysis, a value for the product $\mathrm{k \rho c}$ is obtained where $\mathrm{k}\left(\mathrm{kW} / \mathrm{m}^{\circ} \mathrm{K}\right)$ is the thermal conductivity, $\rho\left(\mathrm{kg} / \mathrm{m}^{3}\right)$ is the density and $c\left(\mathrm{~kJ} / \mathrm{kg}^{\circ} \mathrm{K}\right)$ is the specific heat. Since the samples are thermally thick, the inverse square root time to piloted ignition is given by [6]:

$$
\frac{1}{\sqrt{t_{p}}}=\frac{2}{\sqrt{\pi}} \frac{\left(\dot{\mathrm{q}}_{e}^{\prime \prime}-0.64 \dot{\mathrm{q}}_{\mathrm{cr}}^{\prime \prime}\right)}{\sqrt{\mathrm{k \rho c} \Delta \mathrm{T}_{p}}}
$$

where $\dot{\mathrm{q}}_{\mathrm{cr}}^{\prime \prime}$ is the sum of the convective and reradiation losses at the pyrolysis temperature, $\mathrm{T}_{\mathrm{p}}$. Using this equation, the product kpc can be estimated as input into the upward FSG model. Other input parameters, including the pyrolysis temperature, $T_{p}$, heat of combustion, $\Delta \mathrm{H}_{\mathrm{c}}$, and latent heat of pyrolysis, $\mathrm{L}$, are obtained directly from the small-scale test results [6].

For the plywood samples tested in this project, which were dried in an oven $\left(90^{\circ} \mathrm{C}\right)$ to mimimize humidity, the measured pyrolysis temperature was $310^{\circ} \mathrm{C}\left(583^{\circ} \mathrm{K}\right)$ and the calculated value of the product $\mathrm{kpc}$ was $0.36\left(\mathrm{~kW} / \mathrm{m}^{2}{ }^{\circ} \mathrm{K}\right)^{2} \mathrm{~s}$. The density of the plywood was $600 \mathrm{~kg} / \mathrm{m}^{3}$. Using a value for the specific heat from the literature, $c=3.0 \mathrm{~kJ} / \mathrm{kg}^{\circ} \mathrm{K}$ [7], the estimated value of the thermal conductivity was $\mathrm{k}=0.0002 \mathrm{~kW} / \mathrm{m}^{\circ} \mathrm{K}$. Literature data on $\mathrm{c}$ and $\mathrm{k}$ vary. However, since fire spread depends mainly on the product $\mathrm{kpc}$, as computer sensitivity runs have shown, exact values of $\mathrm{k}$ and $\mathrm{c}$ are not critical to the model.

From the total heat release measurements and total mass loss measurements of the bench scale apparatus, the heat of combustion was $\Delta \mathrm{H}_{\mathrm{c}}=10,000 \mathrm{~kJ} / \mathrm{kg}$. Finally, from the mass loss history measured during pyrolysis, the estimated latent heat of pyrolysis was $\mathrm{L}=200 \mathrm{~kJ} / \mathrm{kg}$.

In the charring model, two additional properties were needed, namely the thermal conductivity, $k_{c}$, and specific heat, $c_{c}$, of the char. Literature values for these parameters, while varying widely, are assumed to be $c_{c}=1 \mathrm{~kJ} / \mathrm{kg}$ and $\mathrm{k}_{\mathrm{c}}=0.00017 \mathrm{~kW} / \mathrm{m}^{\circ} \mathrm{K}$ [7]. Using 


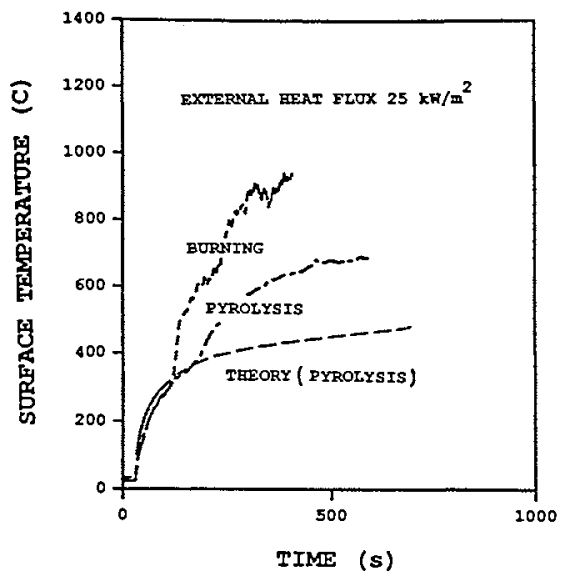

FIGURE 2. Surface temperature history during heat-up and pyrolysis.

these literature values, the surface temperature during charring pyrolysis was predicted and is compared to measured results in Figure 2. For the plot labeled pyrolysis, the sample was placed in a nitrogen environment (10\% oxygen), whereas in the upper curve, the sample was placed in an atmospheric environment and piloted ignition occurred at a pyrolysis temperature of $310^{\circ} \mathrm{C}$ after a heat-up time of $100 \mathrm{~s}$. (The surface temperature measurements are good only up to a time shortly after pyrolysis starts because there was no provision of a spring mechanism to secure the thermocouples to the surface when the surface receded due to pyrolysis. However, some temperature rise may be caused by char oxidation which is not accounted for in the model.) The bottom curve (theory) was calculated using $\mathrm{kpc}=0.36\left(\mathrm{~kW} / \mathrm{m}^{2 \circ} \mathrm{K}\right)^{2} \mathrm{~s}$ and an external heat flux of $25 \mathrm{~kW} / \mathrm{m}^{2}$. The calculated surface temperature provides a good prediction during the pyrolysis phase. Similar predictions for the surface temperature history during heat-up and pyrolysis with higher external heat fluxes of

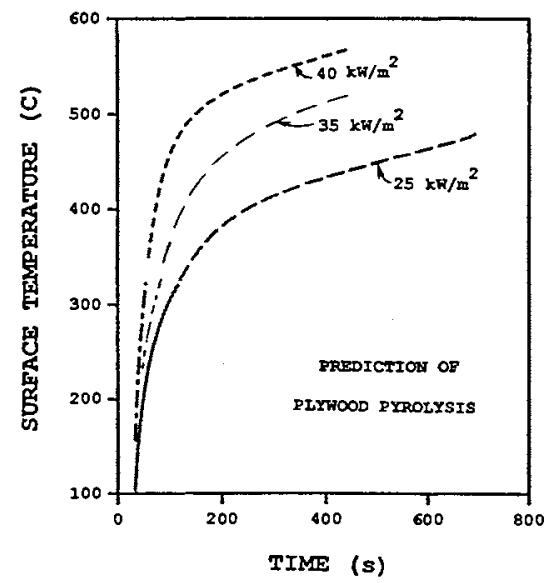

FIGURE 3. Predicted surface temperature history with 25,35 and $40 \mathrm{~kW} / \mathrm{m}^{2}$. 
35 and $40 \mathrm{~kW} / \mathrm{m}^{2}$ are shown in Figure 3. It should be noted that the surface temperature during charring pyrolysis rises to a temperature which is much higher than the initial pyrolysis temperature of $310^{\circ} \mathrm{C}$. The predicted temperatures compare well with the temperatures measured using the full-scale test facility (Figure 8) corresponding to total heat fluxes of $35-40 \mathrm{~kW} / \mathrm{m}^{2}$.
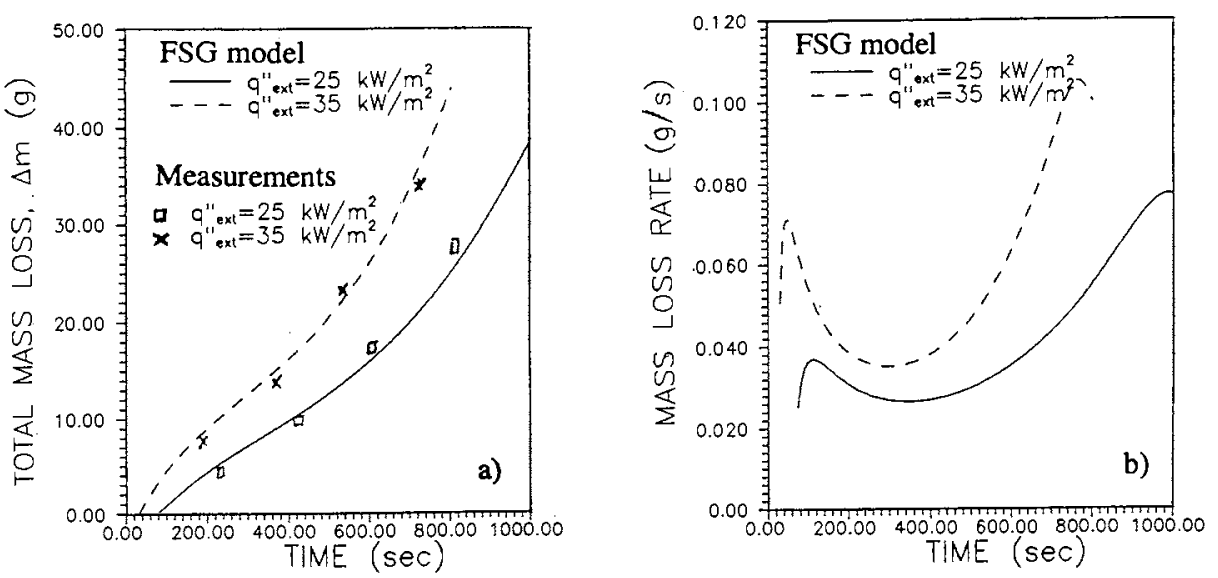

FIGURE 4. FSG predictions of a) total mass loss and b) mass loss rate for $98 \mathrm{~mm}$ diameter plywood specimens during charring pyrolysis.

Figures $4 \mathrm{a}$ and $4 \mathrm{~b}$ show the FSG charring pyrolysis model predictions for mass loss and mass loss rate, respectively during the pyrolysis of the $98 \mathrm{~mm}$ diameter $\left(0.0077 \mathrm{~m}^{2}\right.$ surface area) plywood samples at two external heat fluxes, 25 and $35 \mathrm{~kW} / \mathrm{m}^{2}$. Experimental measurements are also shown in the figures. It is interesting to note that initially the mass loss rate is high, then drops due to char formation, and then rises again when the heat wave is reflected from the back surface. Having obtained the flammability properties from the benchscale tests, the FSG model was next used to predict the large-scale fire spread measurements (Figures $12 \mathrm{a}$ and $12 \mathrm{~b}$ ). These results are discussed below.

\section{FULL-SCALE TEST METHOD}

A large scale (1.5 MW) radiant panel facility was used to provide radiant exposures to the test specimens. This panel was constructed using 40 commercial premixed gas-fired (propane) radiant heaters with porous ceramic tiles used in the front face of the burners. The heaters were mounted in two vertical arrays to provide a flat radiant area $3.6 \mathrm{~m}$ high by $2.7 \mathrm{~m}$ wide.

The radiant flux density produced by the radiant panel depends on the gas supply rate and the distance of the panel from the test specimen. For these tests, the supply rate was maintained constant and the radiant flux varied by changing the distance between the specimen and the panel.

The $0.61 \mathrm{~m}$ wide $\times 2.4 \mathrm{~m}$ high specimens were mounted in a specimen holder which consisted of a steel frame, a balance mechanism, a load cell and a steel supporting structure. The balance mechanism allowed the use of a counterweight for testing heavy specimens which lose relatively little mass during the test. $0.3 \mathrm{~m}$ wide x $2.4 \mathrm{~m}$ high Marinite panels were 


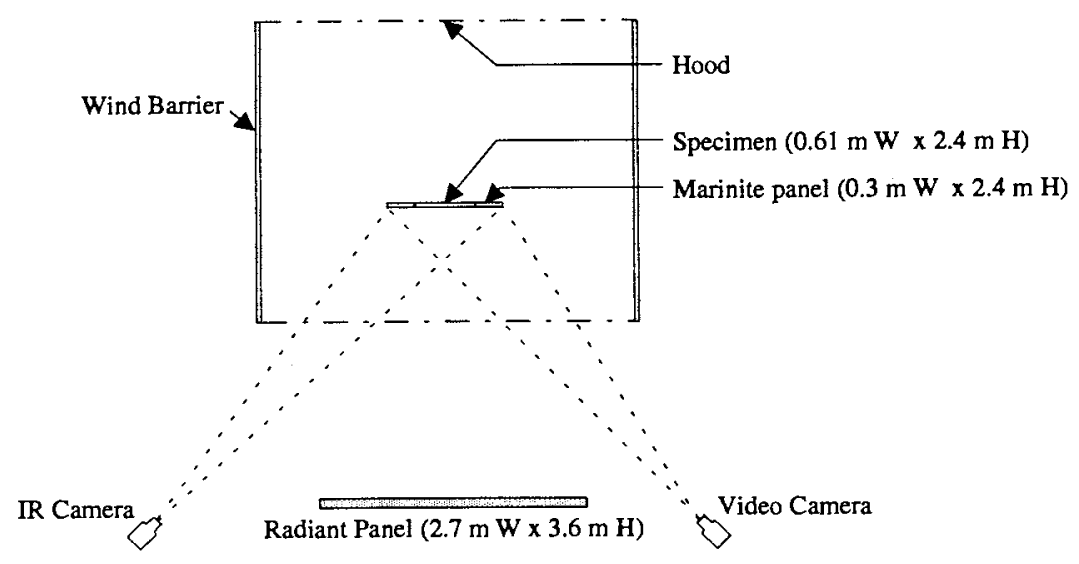

FIGURE 5. Plan view of the test arrangment.

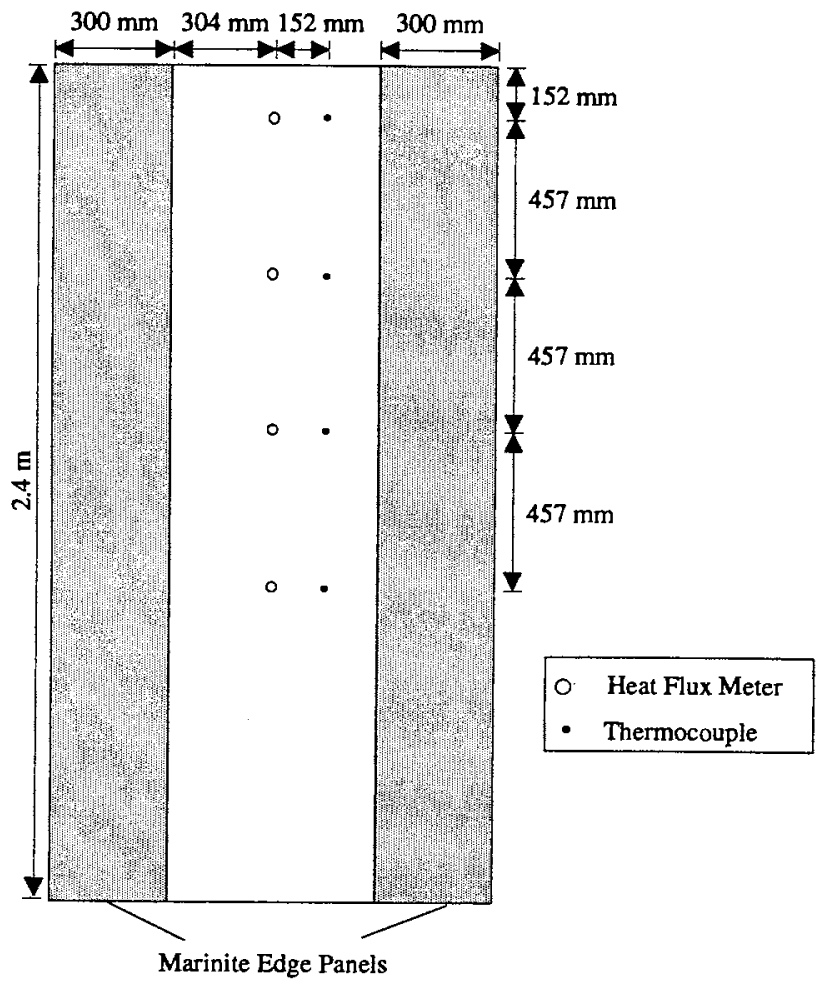

FIGURE 6. Heat flux meter and thermocouple locations. 
positioned on the two sides of the specimen. The front face of the specimen was flush with the front face of the Marinite panels. For the tests discussed in this paper, the non-radiated side of the specimen was uninsulated.

A water-cooled radiation shield was located at the base of the specimen holder. This shield was used to protect the base of the specimen holder including the load cell assembly and the floor in front of the specimen holder. This system also minimized convective heating from the floor to the lower portion of the specimen.

A plan view of the test arrangement is shown in Figure 5. The specimen holder was positioned under a products of combustion collector. This system was fully-instrumented for gas analysis $\left(\mathrm{CO}, \mathrm{CO}_{2}\right.$ and $\left.\mathrm{O}_{2}\right)$, smoke obscuration and heat release measurements.

Other instrumentation included a series of heat flux meters mounted on the centre-line of the specimen as shown in Figure 6. The faces of the heat flux meters were flush with the exposed face of the specimen. Four thermocouples were located at the same heights as the heat flux meters and approximately $154 \mathrm{~mm}$ from the edge of the specimen (Figure 6). A spring loaded system was used to ensure that the thermocouples maintained good contact with the surface of the specimen throughout the test.

Video and IR cameras were used to monitor the front surface of the specimen as shown in Figure 5. The IR camera (Inframetrics Model 600) was provided by the University of Kentucky and used a $10.8 \pm 0.5 \mu \mathrm{m}$ band-pass filter to eliminate radiation from the flame [9]. The automated infrared-image temperature measurement technique was developed at the University of Kentucky with the aim to accurately measure the upward spread rate of a pyrolysis front from a remote location. An initial test was used to set the background temperature for the camera to deduct reflected radiation from the panel. Also, in this test, the temperature history at the thermocouple located at mid-height of the specimen was used to determine the temperature at the pyrolysis front. This isotherm was used in subsequent tests to trace the pyrolysis front.

For the tests, the data acquisition system was started approximately $60 \mathrm{~s}$ before the ignition of the radiant panel. The radiant panel was ignited and the specimen exposed to the radiant flux for $20 \mathrm{~min}$. The panel requires approximately $10 \mathrm{~min}$ to reach steady state conditions, and thus, during the first $10 \mathrm{~min}$ the specimen was exposed to a variable incident flux. After $10 \mathrm{~min}$, the specimen was exposed to a steady radiant flux. The $20 \mathrm{~min}$ initial period allowed sufficient time for the specimen to come to thermal equilibrium.

The specimen was ignited using a red-hot nichrome wire. The wire was preheated using a welder power supply set to provide a $40 \mathrm{Amp}$ current through the wire. After preheating, the wire was brought into direct contact with the specimen at a location approximately $25 \mathrm{~mm}$ above the base of the specimen. A thin spacer located between the specimen holder and the centre of the specimen was used to make the specimen slightly convex at the base and ensure good contact for the ignition wire over the entire width of the specimen.

\section{FULL-SCALE TEST RESULTS AND PREDICTIONS}

A primary objective of the test program, using the large-scale radiant panel, was to obtain reasonably uniform one-dimensional upward flame propagation. That is, the velocities for the flame and pyrolysis fronts should be constant over the entire width of the test specimen. Initial tests were conducted with several materials, including polystyrene foam, polyurethane foam, fire retardant treated plywood and untreated plywood. Flame propagation was observed for all the materials tested except polystyrene. However, for the materials tested, uniform one-dimensional propagation was obtained for only the untreated plywood 
specimens. Modifications to the test arrangement and test procedure will be required before uniform fire spread can be obtained for the other materials tested.

Two untreated plywoods were tested: a) the $12.7 \mathrm{~mm}$ thick rough grade (RG) plywood used for the ASTM E-5 and ISO round robin tests [10] and b) a $12.7 \mathrm{~mm}$ thick good-one-side (G1S) fir plywood obtained locally. The standard plywood was a rough grade with considerable cracks/grain which ran predominately along the length of the specimen and were thus oriented in the vertical direction when mounted in the specimen holder. These cracks made it more difficult to obtain uniform propagation especially with radiant exposures less than $7.5 \mathrm{~kW} / \mathrm{m}^{2}$. With the G1S plywood tested with the finished side exposed, uniform propagation could be obtained with radiant exposures as low as $5.0 \mathrm{~kW} / \mathrm{m}^{2}$.

Heat fluxes, surface temperatures, mass loss rates and heat release rates for a test with

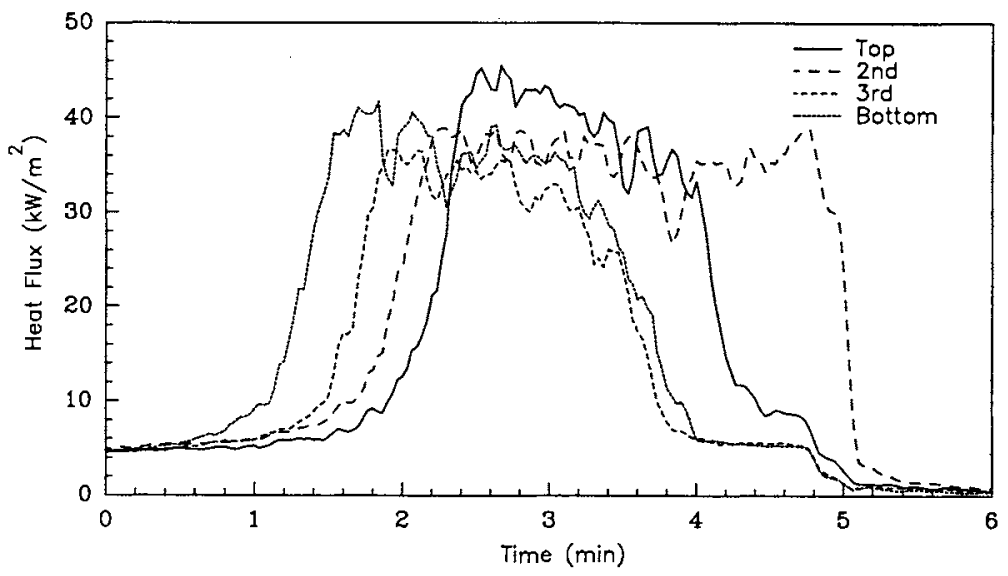

FIGURE 7. Total heat flux to specimen for Test 1 with radiant flux exposure of $5.2 \mathrm{~kW} / \mathrm{m}^{2}$.

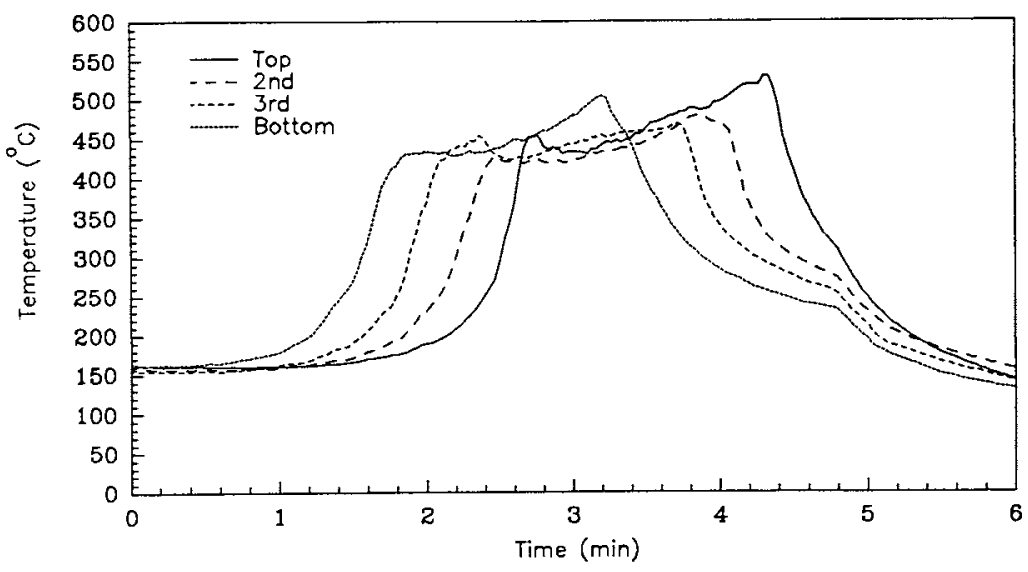

FIGURE 8. Specimen surface temperature for Test 1 with radiant exposure of $5.2 \mathrm{~kW} / \mathrm{m}^{2}$. 


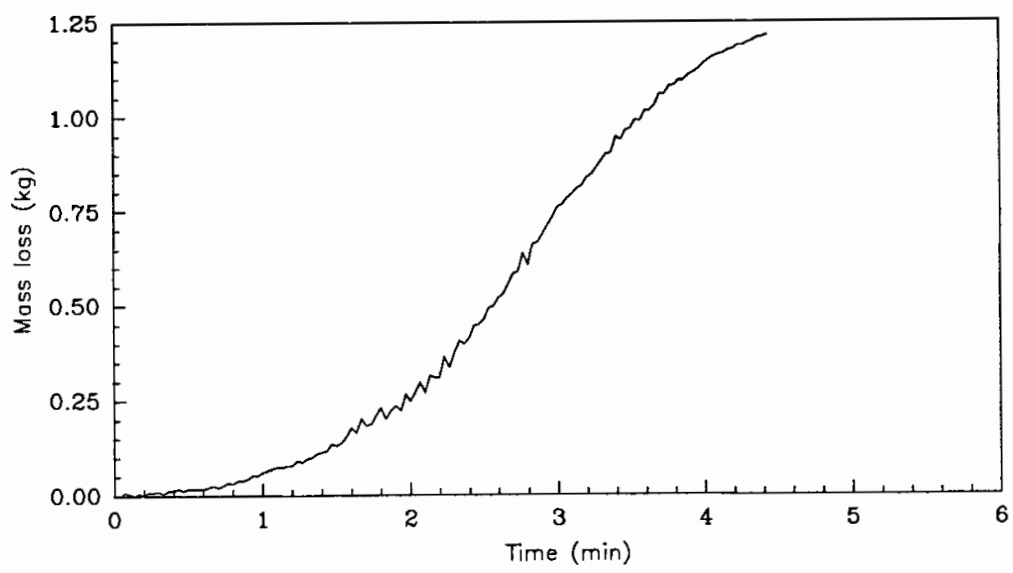

FIGURE 9. Mass loss rate for Test 1 with radiant exposure of $5.2 \mathrm{~kW} / \mathrm{m}^{2}$.

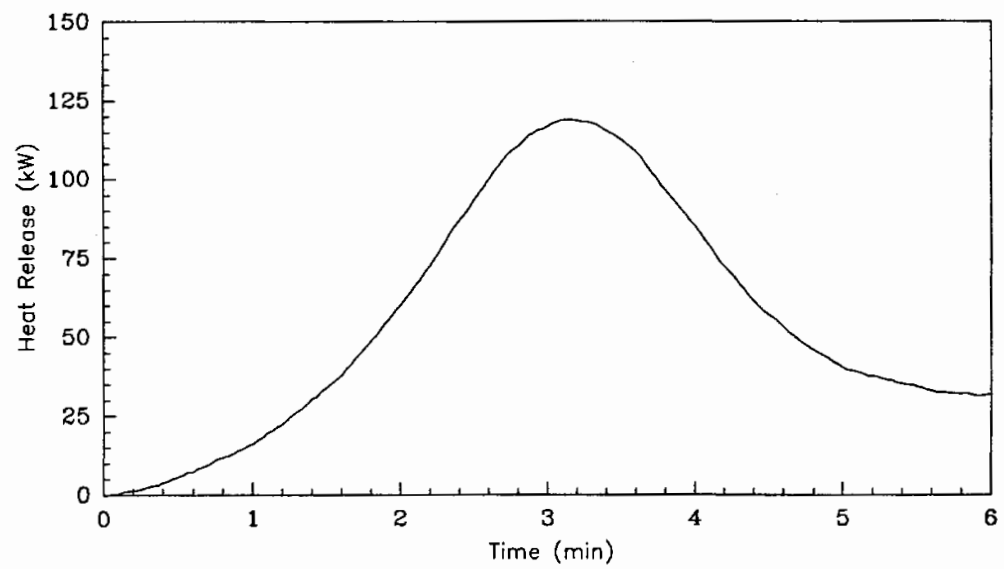

FIGURE 10. Heat release rate for Test 1 with radiant exposure of $5.2 \mathrm{~kW} / \mathrm{m}^{2}$.

the G1S plywood with a radiant exposure of $5.2 \mathrm{~kW} / \mathrm{m}^{2}$ are shown in Figures 7-10, respectively. Time zero on the plots coincides with the time at which the ignition wire contacted the specimen. Typical results measured in this test as well as four other tests with plywood are summarized in Table 1.

With the lower three heat flux meters, there was a rapid increase in the measured heat flux as the flame propagated past the device (Figure 7 ). The measured heat fluxes subsequently remained relatively steady in the range of $34-40 \mathrm{~kW} / \mathrm{m}^{2}$ for $2-3 \mathrm{~min}$. 
TABLE 1. Summary of full-scale test results.

\begin{tabular}{|c|c|c|c|c|c|c|c|}
\hline Test & Plywood & $\begin{array}{c}\text { Radiant } \\
\text { Exposure } \\
\left(\mathrm{kW} / \mathrm{m}^{2}\right)\end{array}$ & $\begin{array}{c}\text { Peak } \\
\text { Heat } \\
\text { Flux } \\
\left(\mathrm{kW} / \mathrm{m}^{2}\right)\end{array}$ & $\begin{array}{c}\text { Initial } \\
\text { Surface } \\
\text { Temp. } \\
\left({ }^{\circ} \mathrm{C}\right)\end{array}$ & $\begin{array}{c}\text { Surface } \\
\text { Temp. } \\
\left({ }^{\circ} \mathrm{C}\right)\end{array}$ & $\begin{array}{c}\text { Mass } \\
\text { Loss } \\
(\mathrm{g} / \mathrm{s})\end{array}$ & $\begin{array}{c}\text { Peak } \\
\text { Heat } \\
\text { Release } \\
(\mathrm{kW})\end{array}$ \\
\hline 1 & G1S & 5.2 & $34-40$ & 160 & $420-450$ & 7.4 & 118 \\
2 & RG & 11 & $45-50$ & 250 & $500-580$ & 14.6 & 250 \\
3 & RG & 7.5 & $40-45$ & 205 & $450-550$ & 11.5 & 130 \\
4 & G1S & 4.8 & $33-38$ & 155 & $420-450$ & 7.2 & 105 \\
5 & G1S & 7 & $40-45$ & 200 & $450-550$ & 12.5 & 175 \\
\hline
\end{tabular}

The heat flux measured by the top heat flux meter was higher than that measured by the other devices (approximately $45 \mathrm{~kW} / \mathrm{m}^{2}$ ). A similar pattern was observed in all five tests with plywood, indicating an increase in the radiation from the flame. This device was within $152 \mathrm{~mm}$ of the top of the specimen and there may be some effect on the flame geometry and the measured heat flux. The peak heat fluxes noted in Table 1 were based on the results measured with the lower three meters.

For this test, the initial surface temperature at ignition was $155^{\circ} \mathrm{C}$ (Figure 8). With flame spread, there was a rapid increase in surface temperature to $420-450^{\circ} \mathrm{C}$. There was a temperature plateau behind the pyrolysis front prior to a secondary increase in the temperature in the latter stages of the test with a maximum temperature of $540^{\circ} \mathrm{C}$ measured by the top thermocouple. However, these secondary peaks occurred during the steady burning phase of the specimen. All temperatures noted in Table 1 refer to those measured during the initial temperature plateau.

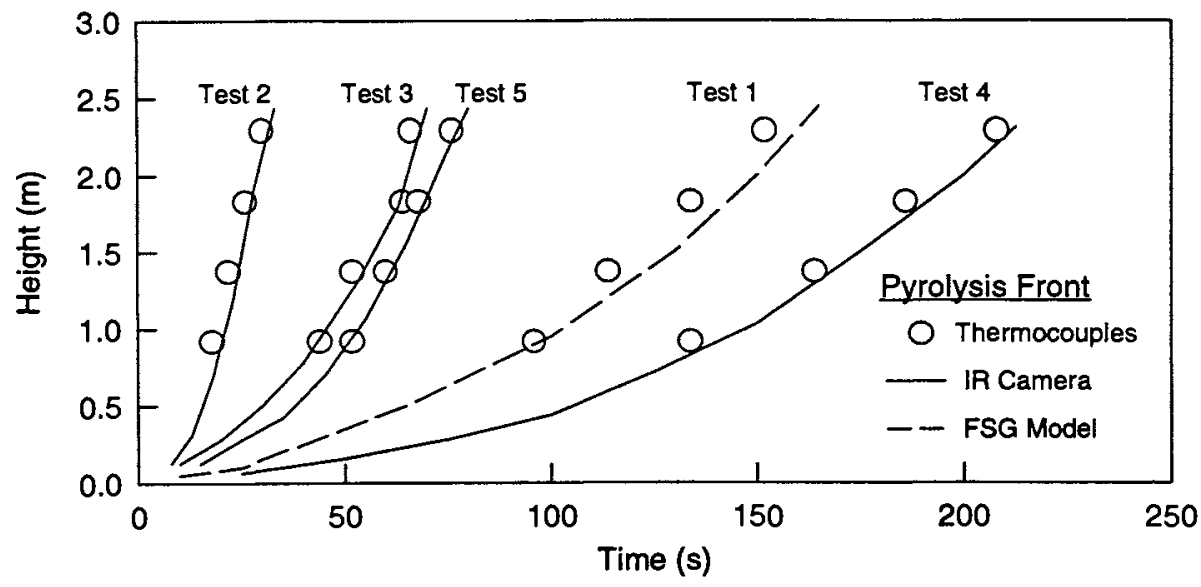

FIGURE 11. Pyrolysis front propagation. 
In the latter stages of the test the average mass loss rate for Test 1 was $7.4 \mathrm{~g} / \mathrm{s}$ and peak heat release rate was $118 \mathrm{~kW}$. The total area of the specimens were $1.464 \mathrm{~m}^{2}$ and thus the peak heat release rates per unit area were in the range of $70-170 \mathrm{~kW} / \mathrm{m}^{2}$ for the five tests with plywood These results are consistent with typical peak heat release rates per unit area measured using small-scale apparatus. Cone calorimeter tests with the RG plywood gave average peak heat release rates of $101 \mathrm{~kW} / \mathrm{m}^{2}$ and $141 \mathrm{~kW} / \mathrm{m}^{2}$ with exposures of 25 and 50 $\mathrm{kW} / \mathrm{m}^{2}$, respectively [11].

The propagation of the pyrolysis front measured using the IR camera and the surface thermocouples are shown in Figure 11 for Tests 2-5. Test 1 was used to calibrate the IR camera and thus IR camera data is not available. In general, there is good comparison between the propagation of the pyrolysis zone measured by the IR camera and the thermocouples. This plot also shows the sensitivity of flame spread to the external exposure.

Having obtained the flammability properties from the bench-scale tests, the FSG model was used to predict large-scale fire spread measurements. Figures $12 \mathrm{a}$ and $12 \mathrm{~b}$ show examples of the FSG model predictions for the large scale specimen. Figure 12a shows the temperature rise history at the bottom of the specimen with a preheat $\left(5.2 \mathrm{~kW} / \mathrm{m}^{2}\right)$ of $20 \mathrm{~min}$. The experimental temperature measured by the four thermocouples in Test 1 is also shown. The temperature rise and steady preheat temperature are well predicted by the model which accounts for both radiative and convective losses. Furthermore, the temperature rise at twenty minutes using a total heat flux of $35 \mathrm{~kW} / \mathrm{m}^{2}$ is also consistent with the measurements.

Figure $12 \mathrm{~b}$ shows the predicted and experimental heat release rates (with time starting at ignition after a twenty minute preheat period). The comparison with the experimental measurement, i.e., a $120-150 \mathrm{~kW}$ peak heat release rate over a period of $120-180 \mathrm{~s}$, is very good.

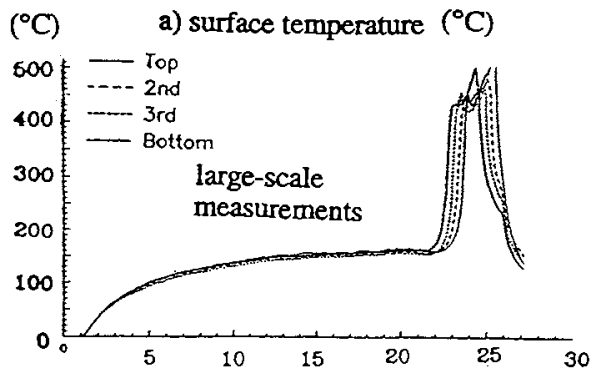

b) heat release rate $(\mathrm{kW})$
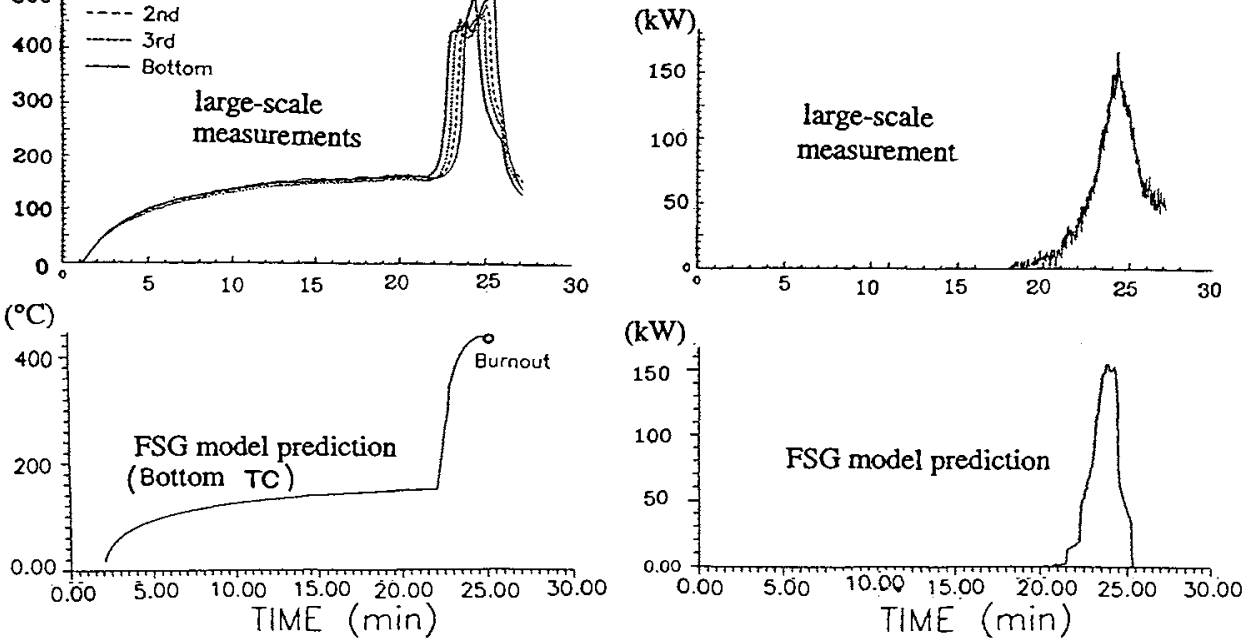

FIGURE 12. FSG model predictions for plywood a) surface temperatures and b) heat release rate for external radiant exposure of $5.2 \mathrm{~kW} / \mathrm{m}^{2}$. 


\section{CONCLUSIONS}

As part of a joint research project between FMRC and NRC, a full-scale test method was developed to provide experimental data for one-dimensional upward flame spread on non-charring and charring building materials for use in developing and validating the FMRC upward FSG model. Results from a series of tests with plywood with radiant exposure in the range of $5-10 \mathrm{~kW} / \mathrm{m}^{2}$ were discussed. Measurements include the propagation of the pyrolysis and flame front, specimen surface temperatures, total heat flux to the specimen, mass loss rates and heat release rates. The full-scale tests demonstrated the sensitivity of the upward flame spread rate to the external radiant exposure. It should be noted that the measured parameters were comparable for the two plywoods used in the test program. Also, the propagation of the pyrolysis front, measured using the IR camera, coincided with that measured using thermocouples proving the usefulness of the IR camera technique for a large scale fire test. The tests also indicate that the total heat flux to the specimen from the flame and the specimen surface temperature were independent of height for heights up to $0.9-1.8 \mathrm{~m}$.

A test procedure for obtaining the properties for the FSG model from bench-scale measurements in the FMRC $50 \mathrm{~kW}$ bench scale flammability apparatus was presented. The simulations using the FMRC FSG model, including a charring pyrolysis module, provided results consistent with the full-scale tests.

\section{REFERENCES}

1. Delichatsios, M.M., Mathews, M.K. and Delichatsios, M.A., "Upward Fire Spread Simulation Code: - Version I: Non-Charring Fuels", FMRC Report J.I. OROJ2.BU, Norwood, MA, 1990.

2. Delichatsios, M.M. and Delichatsios, M.A., "Effects of Transient Pyrolysis on WindAssisted and Upward Flame Spread", Combustion and Flame, 89, 5-16,1992.

3. Saito, K., Quintiere, J.Q. and Williams, F.A., "Upward Turbulent Flame Spread", in Fire Safety Science - Proceedings of the First International Symposium, pp. 75-85, Hemisphere Publishing, 1985.

4. Hasemi, Y, Yoshida, M. and Yasui N., "Upward Flame Spread along a Vertical Charring Material - Experiments and Strategy for Fire Safety Evaluation", 12th UJNR Panel on Fire Research, Tokyo, 1992.

5. Delichatsios, M.A., Chen, Y. and Delichatsios, M.M., "Similarity Solutions for Upward and Wind Assisted Flame Spread and Applications to Non-charring Materials Such as PMMA", ASME Winter Annual Meeting, Anaheim, CA, 1992.

6. Chen, Y., Delichatsios, M.A., and Motevalli, V., "Material Pyrolysis Properties, Part 1: An Integral Model for One-Dimensional Transient Pyrolysis of Charring and Non-charring Materials", Comb. Sci. Tech., 88, 309-328, 1993.

7. Delichatsios, M.A. and Saito, K., "Upward Flame Spread: Key Flammability Properties, Simulation Solutions and Flammability Indices", in Third International Symposium on Fire Safety Science, , pp. 217, Hemisphere Publishing, 1991.

8. Tewarson, A. and Ogden, S.D., "Fire Behavior of Polymethylmethacrylate", Combustion and Flame, 89, 237, 1992.

9. Arakawa, A., Saito, K. and Gruver, W.A., "Automated Infrared Imaging Temperature Measurement with Application to Upward Flame Spread Studies. Part I", Combustion and Flame, 92, 222-230, 1993.

10. Beitel, J.J., "ISR's Fire Research Project", ASTM Standardization News, 36-38, 1990.

11. Onno, R. and Kim, A.K., "Results of Cone Calorimeter Tests Conducted at the NFL/IRC", Internal Report 635, National Research Council Canada, 1992. 